\title{
Renting shacks: Landlords and tenants in the informal housing sector in Johannesburg South Africa
}

\author{
Ashley Gunter
}

Ashley Gunter, University of South Africa, Department of Geography, South Africa (gunteaw@unisa.ac.za)

\begin{abstract}
Renting is a common form of tenure in many developing countries in the global south. This is due to a housing shortage in these countries and has led to a situation where the vast majority of individuals in major cities find accommodation in the rental market. This situation can be put down to the difficulty to entering the market as a homeowner. While this condition is found in much of the formal housing market in the global south, little has been explored in the informal housing market. This state of affairs has pushed many residence in informal settlements into the rental market. This paper examines the rental market in informal settlements in Johannesburg, South Africa by conducting a qualitative investigation into the experiences of landlords $(n=11)$ and tenants $(n=15)$ in three informal settlements in Johannesburg. Overall, there is an asymmetric relationship between the two actors within this market, with the perception that landlords, who view their role as noble provider, impose arbitrary rental terms on tenants in an illegal tenancy market.
\end{abstract}

Keywords: Housing; Informal Sector; Rental; Johannesburg; Informal

\section{Introduction}

Entry to the housing market in many cities in the global south is the informal housing market (Huchzermeyer, 2009; Van Gelder, 2009; Landman \& Napier, 2010; Anand \& Rademacher, 2011). In Johannesburg, for example, 16\% of all the households in the city are found in informal settlements (HAD, 2012). Factors such as high and rising costs of ownership, inability to apply for subsidised housing, irregular and low income have limited access to formal housing by the urban poor. This lack of access is also due, in part, to the lack of formal housing stock at the lower end of the property market (Moolla et al, 2011; Arku et $a l$, 2012). This shortage of formal housing stock is found for both home ownership and within the rental market (Fekade, 2000). The formal low cost housing backlog in Johannesburg is estimated to be approximately one million houses, this number has remained stable over the past 20 years despite the building of a million social houses by the national and local government (HAD, 2012). The backlog indicates the huge influx of immigrants into the city and region and the inability for the social housing sector and the commercial housing sector to keep up with demand for low cost housing (Jenkins \& Smith, 2001; Lemanski, 2009).

The housing shortage has brought about a proliferation of informal settlements and informal dwellings on the periphery of Johannesburg, as well as 'backyard' shacks found in poorer areas of the formal city (Del Mistro \& Hensher, 2009; Lemanski, 2009). A large minority of the residence of the city of Johannesburg live in informal settlements with overcrowding, poor infrastructure, inadequate access to their basic needs and low levels of security (Bénit, 2002).

Yet despite these conditions, the number of informal settlements on the urban fringe is growing, particularly on the northern edge of the city (Cousins et al, 2005). The barriers to development of an informal settlement are relatively low, the biggest obstacle being access to land, once this is secured, though invasion or squatting (in some instances, even purchase by a community), all that is needed is the construction material and knowledge to construct a dwellings (Huchzermeyer \& Karam, 2006; Gunter \& Scheepers, 2012). The demand for 
informal dwellings and the relative ease of supply should lead to an influx of owner occupiers, where new immigrants settlement, construct and live in their own dwellings.

This however, does not seem to be the case, with a significant portion of residence in informal settlements renting their accommodation (Jones \& Datta, 2000; Berner, 2001; Arku, 2011; Gunter, 2013). This rental market takes on a similar situation to the formal renting market, with tenants requiring to 'put down' deposits to secure a rental unit and landlords harbouring some requirements to maintain the residence. This segment of the housing market is severely under researched as the informal housing market is a 'grey' economic space with little to no legal framework and a reluctant constituency, often due to the potential legal status of the resident (Gilbert, 2002). This paper seeks to address this gap by asking two questions, namely, what are the rental experiences of tenants in an informal rental market? Secondly, what are the landlord/tenant relationship dynamics in an informal housing market? The findings of this study hope to provide insight into the dynamics of this informal market as well as develop the debate on the role of the informal sector in developing economies.

\section{Informal Housing in South Africa}

The housing market in South Africa is broadly divided into three sectors, the formal housing sector, characterised by a sophisticated legal framework and financial mechanisms (Huchzermeyer \& Karam, 2006; Rust, 2006). The informal housing sector, characterised by little framework and poor quality access to services and the 'backyard' sector, which has informal dwelling in formal housing suburbs, where residence will live in informal dwellings but often have access to basic services such as water and electricity (Goebel, 2007; de Wet, et al, 2011). For the most part, the urban poor find themselves confined to the informal housing market; here access does not require some of the sophisticated tools for access, such as a bank account or identity documentation (Gerxhani, 2004). For this reason, the informal housing stock plays a critical role in housing provision in the city (Shapurjee \& Charlton, 2013).

The post-apartheid South African government has spent billions of rands in developing social housing (Landman \& Napier, 2010). Much of these developments have been in the form of social housing known as RDP housing, this housing stock is often found in areas previously designated for black Africans under apartheid (Lemanski, 2011). The reason for this development was that during apartheid, urban land for the development of housing for black Africans was restricted, thus there was and still is a severe shortage of low cost housing for new entrants into the city (Charlton \& Kihato, 2006). This lack of housing stock has led to the increase in informal settlements in urban centres and despite the extensive social housing programme, informal settlements and dwellings has continued to develop (Ramabodu et al, 2007; Moolla et al, 2011).

The informal housing market in South Africa is characterised by poverty and lack of control, it is within this sector that the most vulnerable of the urban poor find themselves and equally the sector that provides the least support and poorest legal framework in which transactions take place (Rogerson \& Letsie, 2013). This sector of the housing market is the most likely to be an exploitative neoliberal market, where supply and demand are distorted by access to resources and acceptance of below standard product (Obeng-Odoom, 2011). The informal rental housing stock has led to a number of small scale landlords that rent out rooms within their residence; however, it has also created a larger scale informal landlord who develops informal housing stock on squatted land for the exclusive use of the rental market.

The informal housing sector in South Africa, with its large size and rapid development, has the structure of a neoliberal economic market (Gilbert, 2014). The informal market mirrors the shape of the formal housing market and provided an additional income for many individuals who have benefited from the social housing programmes of the post-apartheid government by renting informal dwellings on their properties (Poulsen, 2010). While this has 
created a class of small scale landlords, the development of large informal settlements on the periphery of urban centres has also opened up a market for the large scale renting of informal dwellings to new arrivals in the city.

The informal housing sector is a vital form of shelter for many of the urban poor, the structure and nature of this market is not clear as it is found in the informal sector (Napier, 2009). However, this sector is a vital source of income and services for the poor and the informal housing sector forms a central part of absorbing new immigrants and impoverished individuals into the urban fabric.

\section{Tenure, Landlordism and Informal Housing}

A brief overview of the key features of the informal rental housing market is now analysed to provide context to the study. As the informal rental market has commonalities with the formal housing market, examples are drawn from the broader low-end rental market to provide a framework in which to analyse the state of the informal housing rental sector. While anecdotally, many informal settlements have a significant proportion of individuals living in rented accommodation, government has placed very little emphasis on tenure within the informal sector (Adebayo, 2011; Maass, 2011). Rather, it has focused on developing formal social housing. Even more critically, government in South Africa has not focused on rental tenure and renting as a viable form of stable tenure. The government's longstanding and targeted approach to home ownership has meant that renting in the low end of the property market has been dominated by private landlords (Lemanski, 2009). The government has gone as far as to specifically preclude building a social housing rental stock from their strategy for providing formal housing (Lemanski, 2011).

Formal rental stock in the low end of the market is fairly rare and the majority of rental accommodation is provided in either informal dwellings within formal suburbs or informal dwellings in informal settlements (Arku et al, 2011). This informal sector has a range of actors, from petty landlords who rent dwellings on their properties to a few large scale landlords who might rent dozens of informal properties. Informal dwellings in this market segment are built without proper planning regulation and are not registered making the growth and development of this segment of the market difficult to determine (Bargain \& Kwenda, 2010).

Tenancy in this market is equally informal, with payments often taking place in cash and oral agreements being the norm. Landlords do not function in any formal market and do not give receipts or record tenancy agreements (Hooper \& Cadstedt, 2014). This places the tenant in a vulnerable situation where rents can be increased without notice and safety regulations and basic maintenance ignored with little recourse. However, because of the lack of formal housing in this segment of the market, tenants have little choice but to accept the conditions, move out or be forcibly removed. In similar informal rental markets in Tanzania, it has been indicated that tenants are at high risk of being evicted as no policy exists to protect them (Cadstedt, 2010).

Equally, because of the tenuous nature of the informal tenant, landlords may often add rental dwellings to a site or add rooms to a dwelling for additional rental income without informing the current tenants (Arku et al, 2011). The relationship between landlord and tenant can be very unfavourable towards the tenant who is in a crowded market.

In many informal rental markets, rental units are rarely advertised and potential renters will find accommodation through social networks like friends and relatives. This means that the rental amounts are difficult to standardise and rental amounts will vary across a city or even across a settlement. As in the formal rental market, rents will rise with location, size of dwelling and quality of the structure (Gilbert, 2003). 
Despite the emphasis of home ownership as a form of tenure by the South African government (Özler, 2007), the rental markets in the country are experiencing significant growth and returns. This demonstrates the huge demand for housing in the country (Pottie, 2004). This situation is mirrored by the informal property market where demand is equally high for property and in formal low income suburbs like Diepsloot in Johannesburg, population densities have tripled in the last 10 years due to the construction of informal dwellings in the 'back yards' of formal social housing (Venter et al, 2004; Todes, 2012). The informal tenancy has thus become the bottom step on the property ladder.

\section{Method}

A qualitative approach was used to understand the tenant/landlord relationship in the informal rental market in settlements in Johannesburg. Participants were selected from three randomly selected low-cost and informal settlements in the city. The formal settlement of Diepsloot and the informal settlements of Radio City and Zandspruit, were randomly chosen out of the 16 low income settlements in Northern Johannesburg.

For this study, in-depth interviews were conducted with informal landlords $(n=11)$ and informal tenants $(n=15)$, the sample size was determined through data saturation. The sample was initially selected through convenience sampling where the researcher identified a willing landlord and tenant to participate in the study. The sampling then continued through snowball sampling. While it is recognised that this sampling method will not create representative sample, this method is most useful when no pre-existing databases of the target population exist. This method is widely used when it is hard to reach and identify the population.

Landlords and tenants from the same household were interviewed, however not at the same time and neither the landlord nor the tenants were privy to the information provided by each other. The individuals were then asked to identify another person who might be interest in participating in the research. They were then asked to contact that person and arrange a meeting between the researchers and the new interviewees. All interviews were conducted by the researcher and an individual from the community fluent in both English and the local vernacular. The interview followed semi-structured interview questions with open ended answers.

Themes and content analysis guided the deconstruction of the interview data with the themes driving the collation of information. All interviews were coded using the same coding scheme depending on whether they were a landlord or tenant. Two researchers independently coded the research and categorised it into themes to compare and analyse. Direct quotes from the transcripts provide context for the coding. The themes identified by the coding were used to unpack the relationship between landlords and tenants in the informal rental market.

\section{The Study Sample}

There were more female tenants (9) interviewees and landlords (7) than males; this could reflect the demographic of inhabitants of informal settlements and the marginalised existence of females in the formal economy that pushes them into the informal economy, both for income and services. Table 1 shows the general characteristics of the sample group.

Table 1. The Profile of the Sample Group

\begin{tabular}{llll}
\hline Profile & Landlords $(\boldsymbol{n}=\mathbf{1 1})$ & Tenants $(\boldsymbol{n}=\mathbf{1 5})$ & Total $(\boldsymbol{n}=\mathbf{2 6})$ \\
\hline Gender & & & \\
\hline Male & 4 & 6 & 10 \\
Female & 7 & 9 & 16 \\
Average age & 52 & 36 & 43
\end{tabular}




\begin{tabular}{|c|c|c|c|c|c|c|}
\hline \multicolumn{7}{|l|}{ Educational Level } \\
\hline \multicolumn{7}{|l|}{ No Schooling } \\
\hline Some Schooling & 4 & & 7 & & 11 & \\
\hline Completed High school & 2 & & 6 & & 8 & \\
\hline Tertiary Education & 1 & & 0 & & 1 & \\
\hline $\begin{array}{l}\text { Average Longevity in } \\
\text { Community (years) }\end{array}$ & 10.9 & & 3.6 & & 14.5 & \\
\hline Nationality & $\begin{array}{l}\text { SA } \\
\text { Citizen }\end{array}$ & Foreigner & $\begin{array}{l}\text { SA } \\
\text { Citizen }\end{array}$ & Foreigner & $\begin{array}{l}\text { SA } \\
\text { Citizen }\end{array}$ & Foreigner \\
\hline & 7 & 4 & 6 & 11 & 13 & 15 \\
\hline
\end{tabular}

It is clear from the table that the average tenant interviewee was a young female foreigner with some schooling who had recently moved into the community while the average landlord interviewee was a middle aged female South African with some education that had been in the community for a number of years.

\section{The Tenant Experience}

The majority experience for the interviewed tenants was that renting in the informal housing market is difficult and unstable. The tenants expressed concerns about security of tenure, the scarcity of 'decent' accommodation, high rental costs and the arbitrary nature of changes and decisions made by the landlord. They claimed that the situation was exacerbated by the large demand for accommodation and that they were aware that if they left their current accommodation there was no guarantee that they would find an alternative, one tenant went on to say:

"In this place there are too many people looking for a house and not enough places, if I go from my shack, there will be 20, 30 people wanting to come here. I cannot move because I will not find another place like this here.” (Tenant Interviewee 10)

There was a clear indication from tenant interviewees that there is a lack of informal housing stock for rental, this is surprising because of the low economic costs to building an informal dwelling. The demand for and supply of housing stock in the surveyed settlements points to a market structure that is demanding higher rents due to high demand and a lack of production to fulfil this demand, one participant stated.

"I cannot just build a shack here; I have to get permission from the [housing] association. You cannot just build so you must rent. These rents [cost] are too much [expensive]. I have no other way but to pay because I cannot build.” (Tenant Interviewee 3)

Other interviewees also pointed to the inability to construct their own dwelling and the high cost of renting when there are no alternatives:

"I have asked the association for permission to build over there by the river, they have not said yes and want money to give me permission. I cannot pay so I must rent." (Tenant Interviewee 2)

"These rents take all my money, I must buy food and fuel but all I do is spend money on rent” (Tenant Interviewee 11) 
Tenant Interviewee 6: "When I came here I wanted to build a shack but I was told that there was no place to build so I must buy or rent, I rent now until I have saved enough to buy a shack."

Researcher: "How much do you need to buy a place?"

Tenant Interviewee 6: “R35 000”

There is an obvious anxiety about the inability to build a dwelling and stress about finding informal renting and the cost of the rental units. The informal housing rental is guided by supply and demand and in settlements in the northern periphery of Johannesburg; there is an indication that demand is outstripping supply.

\section{Tenuous Tenure}

All of the tenants in the study agreed that renting in the informal housing market created insecure tenure and were unhappy with their renting status. They expressed anxiety over the lack of security and the ability of the landlord to extort rent increases as well as evict them without notice. They described the insecurity with varying degrees of displeasure such as 'unstable', 'terrible', 'vulnerable' and often 'scary'. They feared the power relationship that they experienced with their landlord and that they had no recourse to unfair practice such as rent increases. They felt that this created a situation where the tenant with the most buying power could push out the existing occupant. The landlords often using force and intimidation to remove the current tenants to make way for the new.

The tenuous nature of this tenure lead 7 of the participants to express that they 'constantly' worried about the threat of being evicted. These individuals spoke of the desire to build and own their own dwelling within the informal settlement. Tenant interviewee 6 stated:

"I wish I had my own house here, then I wouldn't have to pay rent every month. If I had my own [house] then the landlord won't bother me and I wouldn't have to spend so much money on rent."

Tenant interviewee 3 continues on this trend:

"I was moved from my last house because the landlord wanted more money and I could not give it. I had to take my child and find a new place in one night. Now I'm saving to buy a house here so I don't have to deal with a landlord, but buying is expensive here."

This level of anxiety is often expressed as fear, one participant stated:

"I am so scared that I will be asked to just go, if I hear someone at night, it might just be the landlord telling me to go." (Tenant interviewee 7)

This state of fear is not unique to housing tenure in South Africa. There is a clear trend in informal settlements globally where tenure is insecure; there are heightened levels of stress and anxiety over the issues (Wekesa et al, 2011). In many cities in the global south, this state of insecurity is contributing to the general levels of poor conditions for the urban poor. In Johannesburg, the general level of insecurity was further exacerbated by the perceived criminality of the landlords and their use of gang thugs to intimidate their tenants. One tenant pointed out:

"If you complain about the shack and ask for things to be fixed, the next day there will be some totsies [criminals] hanging around the next day watching you. They won't even greet you when you come out, they just sit and watch. Then you won't complain anymore, because you are scared ... If I could move I would, but where will I find a place that I can afford?" (Tenant Interviewee 1) 
Tenants felt extremely vulnerable and that the verbal tenant agreement between landlords and tenants meant they were never certain about the status of their tenure. Many tenants expressed the efforts they go to maintain their tenancy, by fostering good social relations with the landlord. Yet despite this, most felt that their rights were being abused by the arbitrary imposition of conditions and increase of rent that they currently experienced. They recognised that their current position falls outside the law and thus were left to the mercies of the landlord.

The tenants felt that as long as they were trapped in the informal housing rental market, they would not be able to access the rights of decent housing. They did not feel there was any recourse if they were exploited or evicted and pointed to the lack of maintenance on their dwelling as proof that the landlord was simply there to make money, not to look after the welfare of the occupants. All the interviewees felt that this was an undesirable position to be in and expressed an interest in building or buying their own informal dwelling.

\section{The informal rental market; the landlord's perspective.}

Landlords tended to have a very high opinion of the service they were providing to the tenants and many of the landlords saw their role as service provider in a under serviced market. There was a pride for the provision of this service and a sense of achievement that the landlord has found an alternative income stream in a poor environment. Landlords were aware of the need to provide basic conditions to their tenants, although none would provide a list of basic condition that they saw as essential in their housing stock. In total, 8 of the landlords interviewed rented their property on a month to month payment basis and the remaining 3 rented on a week to week payment basis. The landlords were not willing to divulge the lease agreements, they did however, express that as long as the tenant paid their rent they would have tenure security, landlord interviewee 8 states:

"My tenants pay me once a month, I ask them to pay me on payday so they don't spend all their money before they pay me. If they don't pay I will take away something of value from the house, like a TV, for two weeks, if they still haven't paid me after two weeks then I keep the TV and kick them out. But if they pay, why would I want them to go, good tenants are hard to find, so if they pay I won't ever kick them [out].”

The main concern among the landlords was that their tenants worked in low end or informal jobs and did not always have regular income, this they felt could jeopardise the payment of rents and lead to non-payment. They also felt that the tenants were quite mobile and if they secured alternative accommodation, closer to work or in a more desirable location, they would not give notice but just move out. In total, 6 of the 11 landlords relied on rental income for their living and felt that the threat of non-payment was a significant issue, one rental dependant participant referred to his rental properties as his cattle and how he needed them to provide milk to survive.

Most of the landlords felt that their rental properties were priced reasonably for the level of quality of the informal dwelling, they did feel that the dwelling provided a good return on investment for the capital invested. One landlord explained that it is not profitable to constantly upgrade properties.

Many of the landlords expressed that financing was hard to come by and that they were finding it difficult to make money off the rental incomes they received. They did show remorse about raising rents but were very clear that it needed to be done, as stated:

"I live off my rents, so if the price of living goes up the price of rent has to go up as well. I cannot wait one year, two years to raise the rent, when costs go up I have to cover them now so I raise the rent." (Landlord interviewee 1 ) 
“... petrol goes up, food goes up, taxi fare goes up... so rent goes up, that is how the world works, if they are not happy renting here then they can go find another place. I put up rents so I can make a living, and then the price must go up when my costs go up. (Landlord interviewee 7)

However, when asked if they thought the ability to raise rents indiscriminately, none of the landlords felt that they were doing anything illegal or abusing their positions. This is in sharp contrast to the tenant's view that the indiscriminate raising of rent was a direct abuse of the landlord's access to housing. Landlords also held themselves in high esteem as providers of what they saw as a much needed commodity, housing and did not feel that they were in any way exploiting a vulnerable market.

\section{Discussion of Findings and the Implications}

The findings of this study points to the opposition in the housing market in Northern Johannesburg, with tenants concerned about the quality, price and security of the rental properties. The landlords feel that they provide an essential commodity in an underutilised market. The rental market in these informal areas is exacerbated by the illegal status of the settlements; tenants have no recourse in the law and often do not have much social capital in the local community. Landlords, however, are not accountable to building standards or legal obligations due to this illegality and demonstrate their social standing by the ability to acquire land in the informal economy and build dwellings.

The tenuous state of informal renters creates an environment that is ripe for abuse. Landlords are not accountable and the lack of alternative housing stock point to the ability for there to be exploitation. The shortage of available rental stock has increased the sense of insecurity for informal tenants. This anxiety only increases the overall anxiety of the informal sector resident who is on the margins, not only the economy but even the informal economy (Blunch et al, 2001). The inability to find adequate rental stock in the informal housing sector has also influenced the mobility of renters as they grapple with the task of finding new accommodation if they wish to move. This demonstrates the negative effects of seemingly unrelated aspects of the wellbeing of tenants.

While it is clear that tenants are in a precarious situation, the reliance of landlords on the income from rental units also leaves this group exposed to risks, the challenges of collecting rent from a group of individuals who have irregular incomes and the risk of tenants defaulting leads landlords to feel that they are providing a noble service, rather than exploiting a vulnerable community.

It would appear that with the idea that the provision of informal dwellings for rent is a noble occupation; the raising of rents indiscriminately is justifiable by the landlord. The justification being that if costs are to increase, then this needs to be passed on to the tenant as they are simply fortunate to have a dwelling to rent. Equally, rental income is an important source of income for landlords and if returns on rental properties diminish, landlords are at risk of falling into poverty.

The challenges of the informal housing market are exasperated by the lack of a low cost housing stock; the South African government's inability to reduce the housing backlog has fuelled the demand for informal dwellings as the formal housing stock demands a premium (Huchzermeyer, 2001; Charlton \& Kihato, 2006; Landman \& Napier, 2010). This forces more and more rent seekers into the informal housing sector and impact the landlord/tenant relationship, where the landlord has increasing power due to the high demand for housing. The high demand for informal housing and the economic power of the informal landlord leads many tenants to view the relationship as exploitative, however, in a classical economic model, when demand outstrips supply of any commodity, price will increase and quality can suffer 
(Yates \& Wulff, 2000). This situation is seen in the formal housing sector as well. Thus the formal markets inability to keep pace with supply of formal housing leads to the economic principles being experienced in the informal sector (Lemanski, 2011; Kotze, 2013).

The complexity of the informal housing market and the on-going juxtaposition between landlords and tenants clearly point to the need for policy intervention. There is clear need for some regulation and control of this informal market (Huchzermeyer, 2003). This need to legislate the informal sector is not often present in the South African legislative framework. The informal is often ignored and not governed by formal structures (Chen, 2005). However, in the context of cities in the global south, there are a number of examples of formal legislation being used to govern informal activities (Wells, 2001; Nwaka, 2005; Tipple, 2005). This should be duplicated in the informal housing market in Northern Johannesburg to prevent the exploitation of tenants as well as to prevent the neoliberal market from exploiting a supply gap.

Further, there is a need for a stock of rental social housing. Although it was a government mandated decision to develop social housing for ownership, the creation of a rental housing stock would provide a second revenue stream, through rentals, for the development of more housing.

\section{Conclusion}

The low cost formal housing stock in Johannesburg has simple been unable to develop at the pace of population growth (Todes, 2012). This has seen the increase in the informal housing and many new immigrants into the city are forced to find shelter in these informal settlements. While it would appear that the development of new informal dwellings would be easy for new arrivals, there is clear evidence that ownership informal dwellings are out of reach of the poorest and newest arrivals in cities (Huchzermeyer, 2003). This pushes these individuals into the informal rental market. This market, a by-product of the lack of formal housing, is a classical neoliberal market, where supply is weak and demand constantly high. This places undue stress on the vulnerable in society as they function in the informal economy with little protection and legislative support. Despite this exploitation of renters in the informal markets, many landlords see their role as essential and the function of providing shelter for the poor as a noble cause. This is used to justify the often arbitrary changes in conditions and lack of maintenance of the rental stock. Due to the high demand for rental units in the informal sector, many tenants do not have the choice of moving or finding alternative accommodation. The informal sector is a vital element of the modern developing city, many residence conduct almost all of their economic activities within this informal economy (Rogerson \& Rogerson, 2010). This paper points to the informal housing market as another instance of the importance of the informal sector as well as the exploitation that can take place without the necessary legislation within this sector.

\section{Acknowledgments}

I would like to thank Jayne Rogerson for asking me to contribute to this special issue. I would also like to thank my reviewer for the comments that helped imporve the article and finally I would like to thank the participants who invited me into their homes and helped me in the community.

\section{References}

Adebayo, P. W. (2011) Post-apartheid Housing Policy and a Somewhat Altered State Role: Does Incremental Housing Still Have a Place in South Africa?. The Built and Human Environment Review, 4(2), pp. 3-16. 
Anand, N., \& Rademacher, A. (2011) Housing in the urban age: inequality and aspiration in Mumbai. Antipode, 43(5), pp. 1748-1772.

Arku, G., Luginaah, I., \& Mkandawire, P. (2012) "You Either Pay More Advance Rent or You Move Out”: Landlords/Ladies’ and Tenants’ Dilemmas in the Low-income Housing Market in Accra, Ghana. Urban Studies, 49(14), pp. 3177-3193.

Bargain, O., \& Kwenda, P. (2010) Is Informality Bad? Evidence from Brazil, Mexico and South Africa (No. 4711) Bonn, IZA Discussion Papers:

Berner, E. (2001) Learning from informal markets: Innovative approaches to land and housing provision. Development in Practice, 11(2-3), pp. 292-307.

Bénit, C. (2002) The rise or fall of the 'community'? Post-apartheid housing policy in Diepsloot, Johannesburg. In Urban Forum 13(2), pp. 47-66.

Blunch, N. H., Canagarajah, S., \& Raju, D. (2001) The informal sector revisited: A synthesis across space and time. World Bank Social Protection Discussion Papers, pp. 119.

Bradlow, B., Bolnick, J., \& Shearing, C. (2011) Housing, institutions, money: the failures and promise of human settlements policy and practice in South Africa. Environment and Urbanization, 23(1), pp. 267-275.

Cadstedt, J. (2010) Private rental housing in Tanzania—a private matter?. Habitat International, 34(1), pp. 46-52.

Charlton, S., \& Kihato, C. (2006) Reaching the poor? An analysis of the influences on the evolution of South Africa's housing programme. In Pillay, U., Tomlinson, R., \& du Toit, J., (eds.) Democracy and delivery: Urban policy in South Africa, pp. 252-282. Cape Town, HSRC Press.

Chen, M. A. (2005) Rethinking the informal economy: Linkages with the formal economy and the formal regulatory environment. United Nations University, Helsinki, World Institute for Development Economics Research.

Cousins, B., Cousins, T., Hornby, D., Kingwill, R., Royston, L., \& Smit, W. (2005) Will formalising property rights reduce poverty in South Africa's 'second economy'. Questioning the mythologies of Hernando de Soto. Plaas Policy Brief, (18).

Del Mistro, R., \& A. Hensher, D. (2009) Upgrading informal settlements in South Africa: Policy, rhetoric and what residents really value. Housing Studies, 24(3), pp. 333-354.

de Wet, T., Plagerson, S., Harpham, T., \& Mathee, A. (2011) Poor housing, good health: a comparison of formal and informal housing in Johannesburg, South Africa. International journal of public health, 56(6), pp. 625-633.

Fekade, W. (2000) Deficits of formal urban land management and informal responses under rapid urban growth, an international perspective. Habitat International, 24(2), pp. 127150.

Gerxhani, K. (2004) The informal sector in developed and less developed countries: a literature survey. Public choice, 120(3-4), pp. 267-300.

Gilbert, A. (2002) On the mystery of capital and the myths of Hernando de Soto: What difference does legal title make?. International Development Planning Review, 24(1), pp. $1-19$.

Gilbert, A. (2003) Rental housing: An essential option for the urban poor in developing countries. Ney York, United Nations Human Settlements Programme.

Gilbert, A. (2014) Housing the urban poor. The companion to development studies, pp. 257262.

Gilbert, A., Mabin, A., Mc Carthy, M., \& Watson, V. (1997) Low-income rental housing: Are South African cities different?. Environment and Urbanization, 9(1), pp. 133-148.

Goebel, A. (2007) Sustainable urban development? Low-cost housing challenges in South Africa. Habitat International, 31(3), pp. 291-302. 
Gunter, A., \& Scheepers, L. (2012) “Crisylida Capital”: Hatching Informal Township Property Markets to Benefit Low-Income Residents in Johannesburg, South Africa. Urban Forum, 23(2), pp. 165-180.

Gunter, A. (2013) Creating co-sovereigns through the provision of low cost housing: The case of Johannesburg, South Africa. Habitat International, 39, pp. 278-283.

Hooper, M., \& Cadstedt, J. (2014) Moving Beyond 'Community’Participation: Perceptions of Renting and the Dynamics of Participation Around Urban Development in Dar es Salaam, Tanzania. International Planning Studies, 19(1), pp. 25-44.

Housing Development Agency (HAD) (2012) Gauteng: Informal settlement status. HAD Publishing: Johannesburg.

Huchzermeyer, M. (2001) Housing for the poor? Negotiated housing policy in South Africa. Habitat International, 25(3), pp. 303-331.

Huchzermeyer, M. (2003) A legacy of control? The capital subsidy for housing, and informal settlement intervention in South Africa. International Journal of Urban and Regional Research, 27(3), pp. 591-612.

Huchzermeyer, M. (2009) The struggle for in situ upgrading of informal settlements: a reflection on cases in Gauteng. Development Southern Africa, 26(1), pp. 59-73.

Huchzermeyer, M., \& Karam, A. (eds.) (2006) Informal settlements: A perpetual challenge?. Cape Town, Juta.

Jenkins, P., \& Smith, H. (2001) An institutional approach to analysis of state capacity in housing systems in the developing world: case studies in South Africa and Costa Rica. Housing Studies, 16(4), pp. 485-507.

Jones, G. A., \& Datta, K. (2000) Enabling markets to work? Housing policy in the'new'South Africa. International Planning Studies, 5(3), pp. 393-416.

Kotze, N. (2013) A community in trouble? The impact of gentrification on the Bo-Kaap, Cape Town. Urbani izziv, 24(2), pp. 124-132.

Lemanski, C. (2009) Augmented informality: South Africa's backyard dwellings as a byproduct of formal housing policies. Habitat International, 33(4), pp. 472-484.

Lemanski, C. (2011) Moving up the ladder or stuck on the bottom rung? Homeownership as a solution to poverty in urban South Africa. International Journal of Urban and Regional Research, 35(1), pp. 57-77.

Landman, K., \& Napier, M. (2010) Waiting for a house or building your own? Reconsidering state provision, aided and unaided self-help in South Africa. Habitat International, 34(3), pp. 299-305.

Maass, S. M. (2011) Rental housing as adequate housing. Stellenbosch Law Review= Stellenbosch Regstydskrif, 22(3), pp. 759-774.

Moolla, R., Kotze, N., \& Block, L. (2011) Housing satisfaction and quality of life in RDP houses in Braamfischerville, Soweto: A South African case study. Urbani izziv, 22 (1), pp. 138-143.

Napier, M. (2009) Making urban land markets work better in South African cities and towns: arguing the basis for access by the poor. In Lall, S., Freire, M., Yuen, B., \& Rajack, R., (eds) Urban Land Markets, pp. 71-97, New York, Springer.

Nwaka, G. I. (2005) The urban informal sector in Nigeria: towards economic development, environmental health, and social harmony. Global Urban Development Magazine, 1(1), pp. 1-11.

Obeng-Odoom, F. (2011) The informal sector in Ghana under siege. Journal of Developing Societies, 27(3-4), pp. 355-392.

Özler, B. (2007) Not Separate, Not Equal: Poverty and Inequality in Post-apartheid South Africa. Economic Development and Cultural Change, 55(3), pp. 487-529. 
Pottie, D. (2004) Local government and housing in South Africa: managing demand and enabling markets. Development in Practice, 14(5), pp. 606-618.

Poulsen, L. (2010) A room in the city: Strategies for accessing affordable accommodation. Urban Forum 21(1).

Ramabodu, M. S., Kotze, B. G., \& Verster, J. J. P. (2007) Diversity and value in Africa's real estate: challenges facing property development in South Africa. Journal of Property Investment and Finance, 25(1), pp. 7-22.

Rogerson, C. M., \& Rogerson, J. M. (2010) Improving the local business environment of Johannesburg. Development Southern Africa, 27(4), pp. 577-593.

Rogerson, C. M., \& Letsie, T. (2013) Informal sector business tourism in the global South: Evidence from Maseru, Lesotho. Urban Forum 24(4), pp. 485-502.

Rust, K. (2006) Analysis of South Africa's housing sector performance. Johannesburg. FinMark Trust.

Shapurjee, Y., \& Charlton, S. (2013) Transforming South Africa’s low-income housing projects through backyard dwellings: Intersections with households and the state in Alexandra, Johannesburg. Journal of Housing and the Built Environment, 28(4), pp. 653666.

Tipple, G. (2005) The place of home-based enterprises in the informal sector: evidence from Cochabamba, New Delhi, Surabaya and Pretoria. Urban Studies, 42(4), pp. 611-632.

Todes, A. (2012) Urban growth and strategic spatial planning in Johannesburg, South Africa. Cities, 29(3), pp. 158-165.

Wekesa, B. W., Steyn, G. S., \& Otieno, F. A. (2011) A review of physical and socioeconomic characteristics and intervention approaches of informal settlements. Habitat international, 35(2), pp. 238-245.

Wells, J. (2001) Construction and capital formation in less developed economies: Unravelling the informal sector in an African city. Construction Management and Economics, 19(3), pp. 267-274.

Yates, J., \& Wulff, M. (2000) W (h) ither low cost private rental housing?. Urban Policy and Research, 18(1), pp. 45-64.

Van Gelder, J. L. (2009) Legal tenure security, perceived tenure security and housing improvement in Buenos Aires: an attempt towards integration. International Journal of Urban and Regional Research, 33(1), pp. 126-146.

Venter, C. J., Biermann, S., \& Van Ryneveld, M. (2004) Low-cost housing location in South African cities: empirical findings on costs and benefits.Pretoria. SATC. 